\title{
Relationships Between A and B/A2 Horizons of Three Soils in the Context of Viticulture
}

\author{
José Maria Filippini Alba (Corresponding author) \\ Dept. of Natural Resources, Embrapa Clima Temperado \\ PO Box 403, Pelotas-RS 96010-971, Brazil \\ Tel: 55-53-32758229Ｅ-mail: jose.filippini@embrapa.br \\ Carlos Alberto Flores \\ Dept. of Natural Resources, Embrapa Clima Temperado (retired) \\ PO Box 403, Pelotas-RS 96010-971, Brazil \\ Tel: 55-55-99710-3330Ｅ-mail: cflores@terra.com.br
}

\begin{abstract}
Alberto Miele
Dept. of Enology, Embrapa Uva e Vinho

PO Box 130, Bento Gonçalves-RS 95701-088, Brazil

Tel: 55-54-99975-8677Ｅ-mail: cflores@terra.com.br
\end{abstract}

Received: October 28, 2020 Accepted: February 3, $2021 \quad$ Published: February 19, 2021

doi:10.5296/jas.v9i1.18320 URL: https://doi.org/10.5296/jas.v9i1.18320

\begin{abstract}
The purpose of this study was a comparison of soil parameters among superficial and sub-superficial horizons of three representative type of soils in Vale dos Vinhedos, Brazil, aiming Viticulture in general, but Precision Viticulture (PV) management as specific focus. Basic aspects of Viticulture or PV are still discussed, by instance, sampling procedures, influence of pedology on quality of wine or methods for defining the management zones. Samples were collected according to each horizon, superficial $(0-20 \mathrm{~cm}$ in depth) or sub-superficial (>40 cm in depth), that is, A (all soils), A2 (Neossolo), Bi (Cambissolo), or Bt
\end{abstract}


(Argissolo). Micro-vinification was performed for grapes derived from five classes of soil. The pedological parameters analyzed were granulometric fractions, chemical parameters and degree of flocculation. Data were organized according to a Geographic Information System (GIS) by ten classes of soil. Basic statistical analysis, line graphs, XY plots and factor analysis were used to interpret the physicochemical variables related to horizons, soil and wine. Relative Accumulation Indexes were evaluated for horizons of soil, classes of soil and wine. Data organized by horizon and type of soil showed great dispersion, so outliers were discarded and data organized by class of soil. Correlation of data related to soil horizons, A against A2/B, was evident for macronutrients. Micro-vinification altered content of $\mathrm{K}$ and $\mathrm{P}$ in wine. Relative Accumulation Indexes of soil horizons correlated to declivity, when declivity lesser than $20 \%$ occurred. Fe and $\mathrm{Zn}$ showed correlation among sub-superficial horizon and wine for some classes of soil.

Keywords: composition, GIS, precision agriculture, wine

\section{Introduction}

Precision agriculture, and by extension precision viticulture are related to innovations in pedology since 90s (MacBratney et al., 2003), such as geographic information systems (GIS), remote sensing, spatial variability, or localization systems oriented by satellite, what can be applied to specific agricultural sectors such as the production of grapes, optimization of vine performance, quality of the wine or environmental impacts (Proffitt et al., 2006).

The influence of the soils on the quality of grapes and wines has been worry humanity since remote times. This is not associated to the taste of "minerality" in wine, what would be derived from the rock and soil occurring in the vineyard, hypotheses refuted by recent research (Maltman, 2013), but to the concept of "terroir". Haynes (1999) defines terroir as all the factors above and below the ground that affect the grape during growth that is meteorological, physiographical, pedological, geological and viticultural factors; excluding biological phenomena as pests, diseases, herbicides, mutations, etc. Moreover, the geological factor is ignored outside France and the pedological factor is restricted to texture (Haynes, 2000). Mackenzie and Christy (2005) remarked that the relation vine - soils is a fundamental part of the concept of terroir, a concept born in the "Old World" and being adopted albeit reluctantly in some parts, by the "New World". The concept and role of terroir may be well known but the underlying science is only beginning to understand.

Italian immigrants arrived to the Serra Gaucha, Rio Grande do Sul State (RS), Brazil in the transition of nineteen and twenty centuries, deriving initially in territorial division by little farms, which over time evolving gradually to fruticulture, viticulture, hospitality and tourist (Farias, 2009). Vale dos Vinhedos region is a little valley, delimited by latitudes $29^{\circ} 08^{\prime} 15^{\prime \prime} \mathrm{S}$ to $29^{\circ} 14^{\prime} 26^{\prime \prime} \mathrm{S}$ and longitudes $51^{\circ} 29^{\prime} 48^{\prime \prime} \mathrm{W}$ to $51^{\circ} 37^{\prime} 55^{\prime} \mathrm{W}$, that is only $0,25 \%$ of the Serra Gaúcha territory, where the first geographic indication of Brazilian wines took place (Chimento et al., 2016). Flores et al. (1982) characterized the Vale dos Vinhedos as a complex geomorphology, region with significant contrasts in altitude, slope, and sun exposure, where the occurrence of flat and soft wavy terrains is $14.2 \%$ of the area, and $58.2 \%$ of the area are wavy or strongly wavy terrains; geology is dominated by basalt rocks, and there are three 
main classes of soil, Argissolo (31.1\%), Cambissolo (48.4\%), and Neossolo (13.4\%). Argissolo soils are Ultisols, thus, mineral soils with a strong difference between horizons, high clay content and textural B horizon (Bt). Cambissolo soil are Inceptisols, again mineral soils but with incipient $\mathrm{B}$ horizon $(\mathrm{Bi})$ and a sub-superficial horizon of minimum $10 \mathrm{~cm}$ thickness, underlying an A, Ap (A horizon affected by man procedures), or AB horizon. Neossolo soils are Entisols few developed, shallow, stony and without B horizon.

The Soil Taxonomy - U.S., the World Reference Base for Soil Resources - FAO and the Brazilian System of Soil Classification (BSSC) are the main pedological references for Brazilian Soils (Santos et al., 2018). Anyway, these systems are not exactly equivalent. The Soil Taxonomy - U.S. and the BSSC consider Order, Sub-order, Large Group, Sub-group, Family and Series, however, the BSSC Order depends on the occurrence or absence of diagnostic horizons and the Soil Taxonomy includes also the water circulation (Prado, 2007). The FAO system considers first and second level, with emphasis in the pedogenetical process.

Leuween et al. (2010) discussed the soil-based zoning for viticulture terroir. "Historically, viticultural zoning proved particularly useful in demarcating territories according to their potential to produce wine of a certain quality or wine of a certain typicity", so they continue "more recently, wine producers have become interested in viticultural zoning in order to enhance the technical management of their vineyards. A deeper knowledge of the spatial variability of certain terroir factors has enabled a choice of the best adapted plant material in each of the zones studied". The authors described also the geological and geomorphological models, working in scale lesser than 1:50,000 and complementary to the pedological model. Which is more detailed (scale of 1:20,000 or superior) and expensive. Innovations as digital elevation model, GIS and remote sensing were mentioned too. These concepts approximate the expressions terroir and viticulture zoning with management zone, related to precision agriculture (Yan et al., 2008; Aggelopooulou et al., 2013).

There are several methods for defining management zones. Flores et al. (2011) considered each class of soil as a management zone. So, micro-zoning was implemented in one vineyard of that study (Filippini-Alba et al., 2012) and soil aptitude was evaluated basing on the clay content, level of organic matter, saturation of bases, and stoniness. Cambissolo soil with declivity 20 to $45 \%$ and recommended levels of clay and organic matter showed the better potential for vines development. A new data process by classification allowed clustering of some classes of soil (Filippini-Alba et al., 2014). Filippini Alba et al. (2017) discussed the conventional soil mapping process against the precision agricultural process, based on soil parameters collected according to a regular grid.

Neossolo soils of Vale dos Vinhedos, RS, Brazil has high tannins contend due to its low water stoking capacity (Chavarria et al., 2011). Miele et at. (2014) studied the wines composition derived from the same vineyards considered in this report, so, five class of soils (two argissolos, one cambissolo and two neossolos) and they observed differences of tannin contend, phenols contend and colour index among them. Cabernet grape composition was studies since climate and soil point of view in Brazilian conditions (Warmling et al., 2018). 
Bălc et al. (2018) studied two vineyards in Romania with sandy - clayey soil, similar mineralogy and geology controlled by local aspects. The occurrence of macro-elements in the soil was associated to the mineral detected by ray-X diffraction. Both vineyards showed high contend of $\mathrm{Ca}, \mathrm{Cr}, \mathrm{Sc}$ and $\mathrm{Zn}$ in white grapes, however the black grapes showed only high contend of $\mathrm{Cu}$. Catarino et al. (2018) analyzed whether elemental composition of soil and wine can be related to geographical origin, with multielement determination of 39 elements in soils, grapes, must and wines. Four wines of three denomination of origin were discriminated using $\mathrm{Li}, \mathrm{Mn}, \mathrm{Rb}, \mathrm{Sr}$ and rare earth elements. Soil and wine elemental compositions were occasionally related.

Leuween et al. (2018) reviewed 78 references about "Soil-related terroir factors" since 1969. Inexistence of a "better soil for wine" was confirmed and according to they, contend of berries related to nitrogen, anthocyanins and sugar are influenced by soil, as the mineral and water status of vines. Climate is also an important factor. One conclusion was: "soil-vine interactions have to be taken into account when studying the effect of soil on terroir expression".

As part of a precision agriculture project of Embrapa, the Brazilian Agricultural Research Corporation, this study compared the texture and elemental chemical composition of the superficial and sub-superficial horizons of three classes of soils in a vineyard from Vale dos Vinhedos, RS, Brazil aiming to understand the influence of soil in viticulture context, with specific focus on improving sampling procedures for precision viticulture and management zones defining methods. Wine samples derived from microvinifications of grapes collected in five classes of soil allowed to understand the soil - wine relation.

\section{Method}

\subsection{Study Area}

The experiment was carried out in three vineyards (Figure 1) located in a recognized Winery from Vale dos Vinhedos, RS, Brazil. The vineyards were established with cv. Merlot, clone 347, grafted on the Paulsen 1103 rootstock (Filippini-Alba et al., 2017), on total area of 2.42 ha. Vineyards 1 and 3 were established in 2005 and vineyard 2 in 2006. The vines were conducted vertically and spur-pruned. The altitude of North half of Vineyard 1 is $557 \mathrm{~m}$, then there is a little increment to $564 \mathrm{~m}$ towards South, continuing to a narrow band on Northern part of Vineyard 2. So, a wavy region alternating $578 \mathrm{~m}, 571 \mathrm{~m}$ and $578 \mathrm{~m}$ again, until the end of Cambissolo soil (Figure 1). Vineyard 3 is higher in lateral parts (607 m, East and West) than the central part, falling to $585 \mathrm{~m}$. Thus, Vineyards 1 and 3 are wavy soft relief and Vineyard 2 shows a significant South to North $35 \mathrm{~m}$ descent. The soils were classified in accordance with Santos et al. (2018), as showed in Table 1. 


\section{Macrothink}

Journal of Agricultural Studies

ISSN 2166-0379

2021, Vol. 9, No. 1
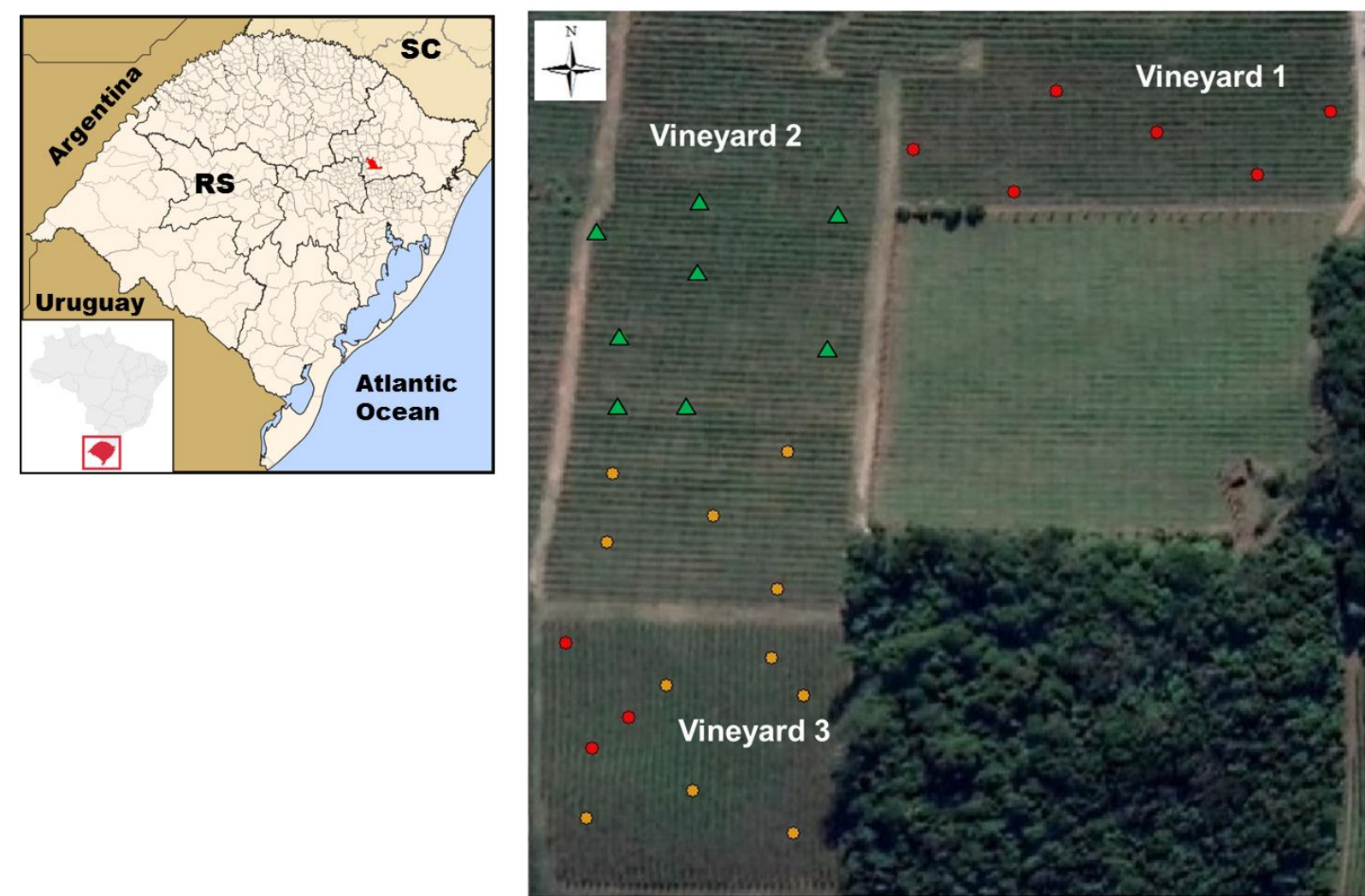

A2 horizon (Neossolo)

$\triangle$ Bi horizon (Cambissolo)

$0 \begin{array}{lllll}0 & 15 & 30 & 60 & \mathrm{~m}\end{array}$

- Bt horizon (Argissolo)

Note: SC/RS = Santa Catarina/Rio Grande do Sul (in red) State.

Figure 1. Location of superficial and sub-superficial soil sampling in vineyards of the study area, Vale dos Vinhedos, Bento Gonçalves (in red), RS, Brazil (in gray). Source image: Google Earth ${ }^{\circledR}$

Table 1. Classification of soil according to the Brazilian System of Soil Classification (BSSC), Soil taxonomy - U.S. (ST - US) and mean characteristics of each unit of soil

\begin{tabular}{|c|c|c|c|}
\hline BSSC & Vineyard & Description & $\begin{array}{l}\text { Horizon Sequence } \\
(\text { depth }, \mathrm{cm})\end{array}$ \\
\hline $\begin{array}{l}\text { Argissolo } \\
\text { (PBAcal1) }\end{array}$ & 3 & Moderately clayey, declivity $3-8 \%$ & $\begin{array}{l}\mathrm{Ap}(15)-\mathrm{Bt} 1(16)-\mathrm{Bt} \\
2(48)-\mathrm{BC}(71)\end{array}$ \\
\hline $\begin{array}{l}\text { Argissolo } \\
\text { (PBAcal2) }\end{array}$ & 1 & $\begin{array}{l}2 \text { Medium clayey to clayey, moderately } \\
\text { wavy, declivity } 8-13 \%\end{array}$ & Without profile \\
\hline $\begin{array}{l}\text { Argissolo } \\
\text { (PBAcal3) }\end{array}$ & 1 & $\begin{array}{l}\text { Clayey loam to clayey, wavy, declivity } \\
13-20 \%\end{array}$ & $\begin{array}{l}\mathrm{Ap}(24)-\mathrm{Bt} 1(18)-\mathrm{Bt} \\
2(37)-\mathrm{BC}(71)\end{array}$ \\
\hline $\begin{array}{l}\text { Cambissolo } \\
\text { (CXve1) }\end{array}$ & $1 \& 2$ & Clay loam to clayey, declivity $13-20 \%$ & Without profile \\
\hline $\begin{array}{l}\text { Cambissolo } \\
\text { (CXve2) }\end{array}$ & 2 & Clay loam to clayey, declivity $20-45 \%$ & Without profile \\
\hline $\begin{array}{l}\text { Cambissolo } \\
\text { (CXve3) }\end{array}$ & $1 \& 2$ & $\begin{array}{l}\text { Clay loam to clayey, stony, declivity } \\
20-45 \%\end{array}$ & $\begin{array}{l}\mathrm{Ap}(14)-\mathrm{AB}(21)-\mathrm{Bi}( \\
40)-\mathrm{BC}(80)\end{array}$ \\
\hline
\end{tabular}




\begin{tabular}{|c|c|c|c|}
\hline $\begin{array}{l}\text { Neossolo } \\
\text { (RRh1) }\end{array}$ & 3 & $\begin{array}{l}\text { Sandy clay-loam to loam, stony, declivity } \\
3-8 \%\end{array}$ & Without profile \\
\hline $\begin{array}{l}\text { Neossolo } \\
(\mathrm{RRh} 2)\end{array}$ & 3 & $\begin{array}{l}\text { Sandy clay-loam to loam, stony, declivity } \\
8-13 \%\end{array}$ & Without profile \\
\hline $\begin{array}{l}\text { Neossolo } \\
\text { (RRh3) }\end{array}$ & $2 \& 3$ & $\begin{array}{l}\text { Sandy clay-loam to loam, stony, declivity } \\
13-20 \%\end{array}$ & Without profile \\
\hline $\begin{array}{l}\text { Neossolo } \\
(\mathrm{RRh} 4)\end{array}$ & 2 & $\begin{array}{l}\text { Sandy clay-loam to loam, stony, declivity } \\
20-45 \%\end{array}$ & $\begin{array}{l}\mathrm{A} 1 \mathrm{p}(25)-\mathrm{A} 2(36)-\mathrm{C} \\
\mathrm{R}(109)\end{array}$ \\
\hline
\end{tabular}

$\mathrm{Ap}=\mathrm{A}$ horizon affected by man procedures.

\subsection{Soil Sampling Methods}

A regular network of 10mx10m was georeferenced in January 2011 by means of a Sokkia SET 610 total station and a Sokkia GSR 2600 global receiver. Samples of A horizon were collected with shovel in January 2011. Altimetry and slope maps were elaborated based on WGS 84 reference system.

Sub-superficial sampling was performed at 28 points by chance in the regular network, after a year. A shovel cutting was used to collect samples in the sub-horizon of $40-60 \mathrm{~cm}$ in depth, so that, 11 samples were collected in the A2 horizon (Neossolo soil), 8 samples were collected in the Bi horizon (Cambissolo soil), and 9 samples were collected in the Bt horizon (Argissolo soil). There were no samples in CXve1 and RRh3.

\subsection{Physicochemical Analysis of Soils}

Physicochemical analyses were performed on the Soil Laboratory of Federal University of Rio Grande do Sul State (UFRGS), including nutrients determination (C, N, Al, Ca, K, Mg, $\mathrm{Na}$, and $\mathrm{P}$ ), micronutrients $(\mathrm{Fe}, \mathrm{Cu}, \mathrm{Mn}$ and $\mathrm{Zn}$ ), granulometric fractions (coarse sand, fine sand, silt and clay), degree of flocculation and pH, according to Embrapa (1997).

\subsection{Micro-Vinification}

Five wines were made with Merlot grapes collected in the classes of soils $R R h 1 / R R h 2, R R h 4$, CXve2/CXve3, PBAcal1 and PBAcal2/PBAcal3, in 2011 with $40 \mathrm{~kg}$ of grapes and two repetitions each one (microvinification). Wines were analyzed in the Laboratories of Embrapa Uva e Vinho, Bento Gonçalves, RS, Brazil, including $\mathrm{pH}$, macronutrients and micronutrientes in similar way than soils samples, aiming comparison.

\subsection{Data Processing}

Data were organized and partially processed by the Geographic Information System ArcGIS (Esri®). Statistical analyzes were performed by the Statistical Package for Social Sciences, SPSS (IBM®). Groups of samples were organizer initially by first order of the Brazilian System of Soil Classification - BSSC for each horizon A, A2, Bt and Bi. However, great data dispersion was observed by some variables. So, some outliers were discarded, due to $\mathrm{P}$ extreme values (superficial data, 6 samples) or sum of variables expressed as percentage of the mean (sub-superficial data, 3 samples). New datasets were organized according to the classes of soil (Table 1). Nonparametric test of Kruskall-Wallis allowed evaluating the 


\section{Ml Macrothink}

influence of the classes of soil on total variance. Means for each class of soil were calculated for samples of soil horizon and wine. Data comparison considered statistics, line graphs, scatter-grans and factor analysis. The level of elements accumulation in the soil horizons or in wine for each class of soil was study considering values of macronutrients and micronutrients expressed as percentage of the mean of each horizon or wine. Values lesser than $65 \%$ were considered impoverished, the interval $65 \%$ to $135 \%$ was considered background level and enriched values were those greater than $135 \%$, when the digits $-1,0$ and 1 were attributed respectively. The sum of these digits produced a relative accumulation index of each soil horizon or wine.

\section{Results}

\subsection{Statistical Pre-treatment}

Coefficient of variation showed values lesser than 30\%, values between $30 \%$ and $100 \%$ and some extreme values in the case of Al and P mainly (Table 2). Brown (1998) remarked: "the coefficient of variation exceeding say about 30 percent is often indicative of problems in the data or that the experiment is out of control. Means less than unity also provides spurious results and the coefficient of variation will be very large and often meaningless". Extreme values of $\mathrm{Al}$ were consequence of great dispersion due to high standard deviation and low mean. The A horizon of the Cambissolo soil presented contend of $\mathrm{Al}$ of $45 \mathrm{mg} \cdot \mathrm{kg}^{-1}$ for a unique sample and null value for the other 7 samples, inducing an anomaly of the coefficient of variation (spurious value). $\mathrm{P}$ values were greater in the $\mathrm{A}$ horizon than in the sub-superficial horizon, always with high dispersion. So, data were regrouped and some outliers discarded as explained before.

Table 2. Mean (M, indicated unit) and Coefficients of variation $(\mathrm{CV}, \%)$ for groups of samples organized by first order of BSSC and soil horizon. C/FSand = Coarse/Fine Sand, \%; Silt and Clay in \%; FD = Flocculation Degree, \%; $\mathrm{pH}$ dimensionless; OrgC = Organic C, N, $\mathrm{Al}, \mathrm{Ca}, \mathrm{Mg}, \mathrm{Na}, \mathrm{K}$ and $\mathrm{P}$ in $\mathrm{mg} \cdot \mathrm{kg}^{-1} ; \mathrm{BS}=$ Base saturation, \%

\begin{tabular}{|c|c|c|c|c|c|c|c|c|c|c|c|c|}
\hline \multirow{3}{*}{ Variable } & \multicolumn{4}{|c|}{ Argissolo (9 samples) } & \multicolumn{4}{|c|}{ Cambissolo (8 samples) } & \multicolumn{4}{|c|}{ Neossolo (11 samples) } \\
\hline & \multicolumn{2}{|c|}{ A horz. } & \multicolumn{2}{|c|}{ Bt horz. } & \multicolumn{2}{|c|}{ A horz. } & \multicolumn{2}{|c|}{ Bi horz. } & \multicolumn{2}{|c|}{ A horz. } & \multicolumn{2}{|c|}{ A2 horz. } \\
\hline & M & $\mathrm{CV}$ & M & $\mathrm{CV}$ & M & $\mathrm{CV}$ & M & $\mathrm{CV}$ & M & $\mathrm{CV}$ & M & $\mathrm{CV}$ \\
\hline Csand & 26 & 18 & 22 & 53 & 27 & 18 & 16 & 86 & 29 & 28 & 29 & 44 \\
\hline Fsand & 8 & 27 & 9 & 50 & 9 & 19 & 6 & 49 & 11 & 34 & 11 & 37 \\
\hline Silt & 34 & 23 & 24 & 25 & 30 & 32 & 29 & 21 & 27 & 26 & 27 & 19 \\
\hline Clay & 32 & 25 & 46 & 40 & 35 & 38 & 49 & 40 & 32 & 44 & 33 & 48 \\
\hline FD & 23 & 64 & 24 & 34 & 27 & 72 & 28 & 39 & 30 & 72 & 33 & 25 \\
\hline $\mathrm{pH}$ & 6 & 8 & 5 & 9 & 6 & 7 & 5 & 8 & 6 & 7 & 5 & 11 \\
\hline OrgC & 2094 & 42 & 1041 & 49 & 1956 & 31 & 979 & 30 & 2552 & 45 & 1785 & 100 \\
\hline $\mathrm{N}$ & 211 & 42 & 118 & 35 & 209 & 25 & 111 & 29 & 245 & 38 & 166 & 87 \\
\hline $\mathrm{Al}$ & 0 & 0 & 147 & 165 & 6 & 283 & 128 & 145 & 0 & 0 & 103 & 165 \\
\hline $\mathrm{Ca}$ & 2090 & 28 & 1305 & 47 & 2128 & 14 & 1509 & 34 & 2590 & 33 & 1498 & 53 \\
\hline $\mathrm{Mg}$ & 281 & 40 & 273 & 42 & 302 & 21 & 284 & 33 & 338 & 22 & 230 & 50 \\
\hline $\mathrm{Na}$ & 8 & 21 & 7 & 27 & 8 & 22 & 5 & 59 & 30 & 234 & 6 & 62 \\
\hline $\mathrm{K}$ & 207 & 37 & 118 & 38 & 226 & 31 & 93 & 20 & 243 & 24 & 131 & 34 \\
\hline $\mathrm{P}$ & 63 & 59 & 8 & 113 & 76 & 73 & 4 & 60 & 128 & 85 & 14 & 103 \\
\hline BS & 80 & 9 & 62 & 29 & 73 & 18 & 70 & 19 & 80 & 13 & 62 & 41 \\
\hline
\end{tabular}




\subsection{Statistical Treatment for Classes of Soil}

Means of the chemical variables for classes of soil and soil horizons are presented in Table 3. Chemical elements were usually richer in A horizon than in the respective sub-superficial horizon and $\mathrm{pH}$ was less acid in A horizon. $\mathrm{Al}, \mathrm{OrgC}, \mathrm{N}, \mathrm{pH}, \mathrm{Ca}, \mathrm{Mg}, \mathrm{K}$ and $\mathrm{P}$ were significant in $20 \%$ level for Kruskall-Wallis nonparametric test. CSand, Fsand, Clay, FD and $\mathrm{Na}$ were included also by the sub-superficial horizon means, with the exception of $\mathrm{N}$. $\mathrm{Na}$ is a special case due to the anomaly for A horizon of RRh1, verified in only one point. Absence of significance for the granulometric variables and FD in the A horizon appears as main difference between A horizon and sub-superficial horizon behaviors. Line graphs help for interpreting data (Figure 2). Clay content and chemical variables suggest discrimination between the different classes of soil. Strong contrast between Al values in superficial and sub-superficial horizons was evident, like as the low contrast for content of silt. Anomaly of $\mathrm{Na}$ was evident for RRh1 in A horizon (NA1).

Table 3. Means for the chemical variables by class of soil and horizons A and sub-superficial. Horz $=$ Horizon; $\mathrm{Rp}=$ repetition

\begin{tabular}{ccccccccccccc}
\hline Class of soil & Horz & $\mathrm{Rp}$ & $\mathrm{pH}$ & $\mathrm{Ca}$ & $\mathrm{Mg}$ & $\mathrm{Na}$ & $\mathrm{K}$ & $\mathrm{P}$ & $\mathrm{Zn}$ & $\mathrm{Cu}$ & $\mathrm{Mn}$ & $\mathrm{Fe}$ \\
\hline CXve2 & $\mathrm{A}$ & 2 & 5.6 & 2145 & 358 & 7 & 219 & 75 & & & & \\
CXve3 & $\mathrm{A}$ & 4 & 5.7 & 1945 & 276 & 8 & 184 & 42 & & & & \\
PABcal1 & $\mathrm{A}$ & 2 & 6.5 & 2576 & 401 & 8 & 309 & 69 & & & & \\
PABcal2 & $\mathrm{A}$ & 4 & 6.2 & 1945 & 237 & 9 & 203 & 57 & & & & \\
PABcal3 & $\mathrm{A}$ & 2 & 5.6 & 1393 & 164 & 6 & 109 & 29 & & & \\
RRh1 & $\mathrm{A}$ & 3 & 6.5 & 3181 & 389 & 87 & 189 & 64 & & & & \\
RRh2 & $\mathrm{A}$ & 2 & 6.3 & 2657 & 358 & 10 & 239 & 76 & & & & \\
RRh4 & $\mathrm{A}$ & 3 & 6.1 & 1952 & 284 & 7 & 275 & 96 & & & & \\
CXve2 & $\mathrm{Bi}$ & 2 & 5.6 & 1714 & 298 & 3 & 109 & 4 & 2 & 11 & 43 & 1 \\
CXve3 & $\mathrm{Bi}$ & 5 & 5.0 & 1436 & 294 & 7 & 84 & 3 & 2 & 10 & 31 & 1 \\
PABcal1 & $\mathrm{Bt}$ & 3 & 5.7 & 1952 & 324 & 5 & 160 & 20 & 4 & 14 & 43 & 2 \\
PABcal2 & $\mathrm{Bt}$ & 4 & 5.0 & 1128 & 298 & 8 & 113 & 2 & 2 & 7 & 34 & 2 \\
PABcal3 & $\mathrm{Bt}$ & 2 & 5.0 & 692 & 146 & 6 & 65 & 2 & 4 & 10 & 93 & 2 \\
RRh1 & $\mathrm{A} 2$ & 3 & 4.9 & 1069 & 186 & 8 & 102 & 5 & 1 & 3 & 25 & 2 \\
RRh2 & $\mathrm{A} 2$ & 2 & 5.0 & 1424 & 261 & 7 & 88 & 24 & 2 & 4 & 14 & 3 \\
RRh4 & $\mathrm{A} 2$ & 4 & 6.0 & 1759 & 246 & 3 & 163 & 13 & 3 & 9 & 30 & 1 \\
\hline
\end{tabular}



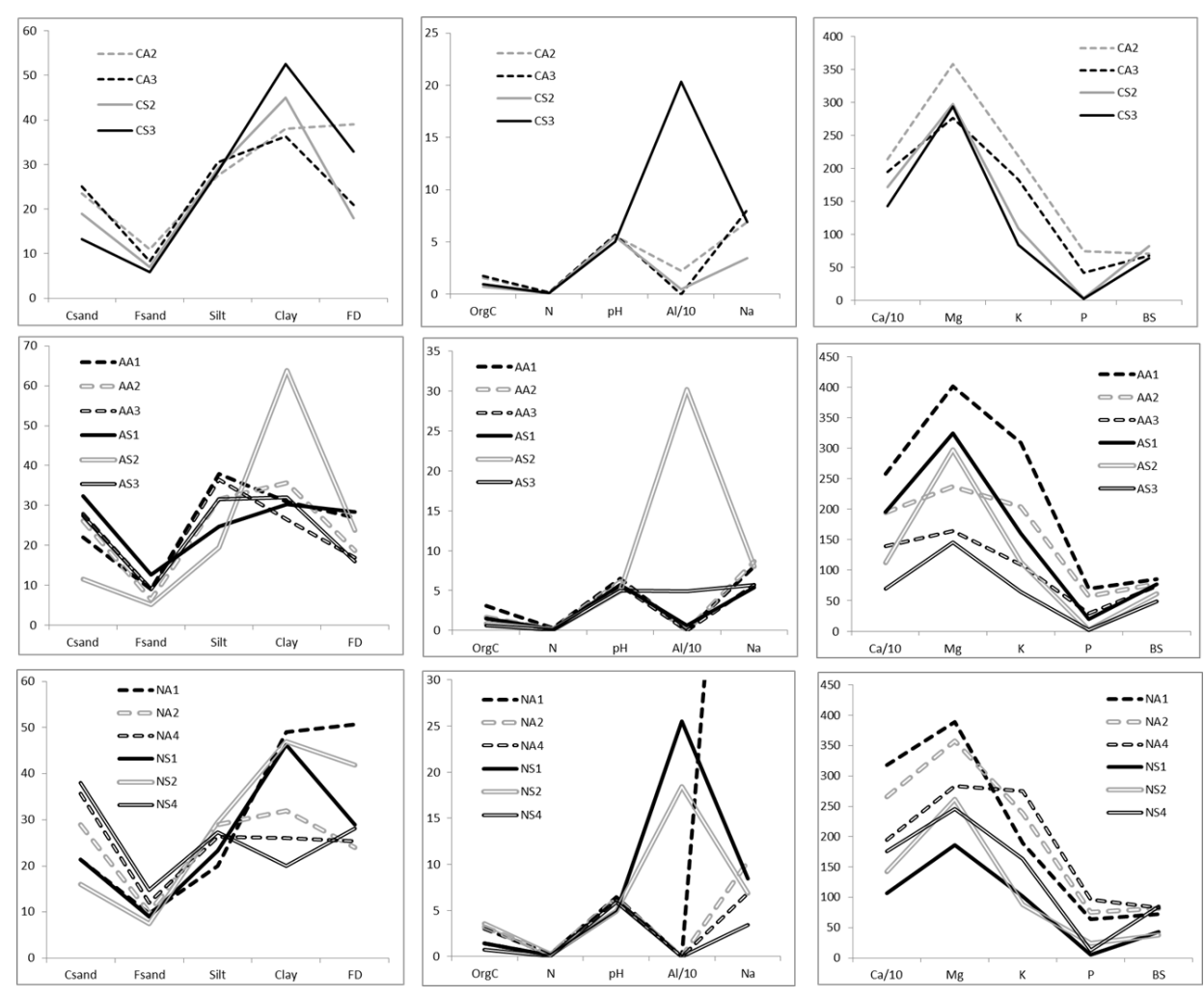

Figure 2. Line graphs for the chemical variables according to eight classes of soil and A or B horizon. Symbols of lines: $1^{\text {st }}$ letter corresponds to first order of BSSC; $2^{\text {nd }}$ letter represents the horizon (A or S for A2, Bi or Bt), and number corresponds to the class of soil. So, AA1 is A horizon for PBAcal1, CS2 is Bi horizon for CXve2, etc. CSand, FSand, Silt, Clay, FD and $\mathrm{BS}$ in \%, $\mathrm{pH}$ dimensionless, other in $\mathrm{mg} \cdot \mathrm{kg}^{-1}$.

\subsection{Wine Composition and Comparison with Soils}

Elemental chemical composition of wines was similar for all cases (Table 4). Coefficients of variation were low; however $\mathrm{P}, \mathrm{Fe}, \mathrm{Mn}$ and $\mathrm{Zn}$ showed a moderately increment. XY plots with label identification of each sample were used for evaluating correlations, that is, linearity, due to the dispersion showed by soil data and the punctual nature of information. K-P and $\mathrm{pH}-\mathrm{Ca}$ plots (Figure 3) confirm linearity of soil samples; anyway, there was some dispersion. The correlations were significant for pairs of the elements $\mathrm{pH}, \mathrm{Ca}, \mathrm{K}, \mathrm{Mg}$ and $\mathrm{P}$. Contend of $\mathrm{K}$ in wine showed a great jump when compared to soil, what suggested an intensive influence of vinification process (Figure 3). The $\mathrm{pH}-\mathrm{Ca}$ plot located wines samples in low values of $\mathrm{pH}$ and $\mathrm{Ca}$ with a big jump between both sets of samples too; the correlation soil-wine was discarded in this case because of absence of linear pattern of wine samples when the scale was amplified. 


\section{Macrothink}

Table 4. Means of $\mathrm{pH}$ and contents of the chemical elements in wine from the mentioned soils (two repetitions). Variables in $\mathrm{mg} \cdot \mathrm{kg}^{-1}$, except $\mathrm{pH}$

\begin{tabular}{lrrrrrrrrrr}
\hline Soil class & pH & Ca & Mg & Na & K & P & Zn & Cu & Mn & Fe \\
\hline RRh4 & 3,8 & 71 & 80 & 9,0 & 1160 & 81 & 1,2 & 0,3 & 3,8 & 0,8 \\
RRh1/2 & 3,7 & 73 & 80 & 9,2 & 1278 & 165 & 0,8 & 0,3 & 3,7 & 0,7 \\
PBACal1 & 3,8 & 80 & 88 & 9,5 & 1240 & 156 & 1,2 & 0,3 & 5,1 & 0,8 \\
PBACal2 & 3,8 & 72 & 83 & 9,0 & 1208 & 114 & 1,6 & 0,4 & 4,5 & 1,1 \\
Cxve1/2/3 & 3,7 & 72 & 82 & 8,4 & 1138 & 105 & 1,1 & 0,3 & 4,4 & 1,1 \\
\hline CofV $(\%)$ & $\mathbf{1}$ & $\mathbf{5}$ & $\mathbf{4}$ & $\mathbf{4}$ & $\mathbf{5}$ & $\mathbf{2 8}$ & $\mathbf{2 2}$ & $\mathbf{8}$ & $\mathbf{1 4}$ & $\mathbf{2 0}$ \\
\hline
\end{tabular}

CofV $=$ Coefficient of Variation
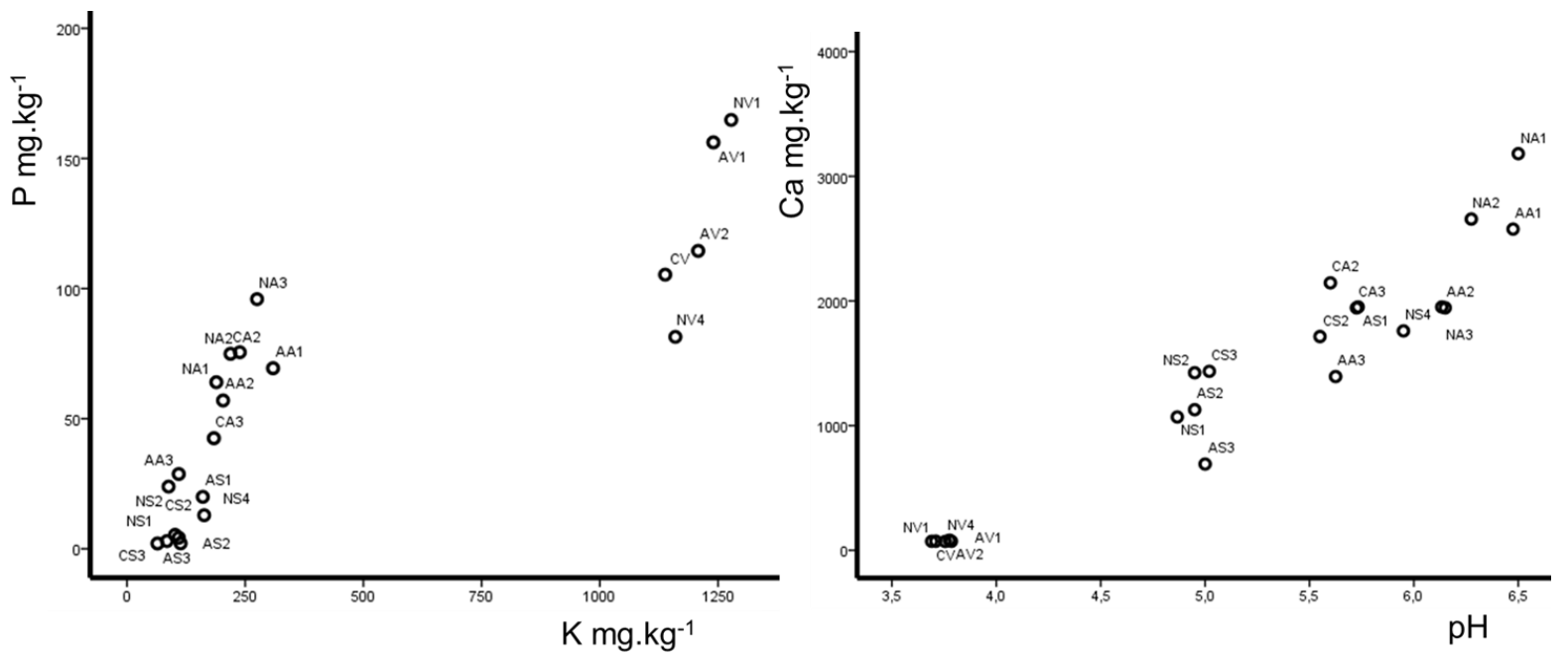

Figure 3. Comparative $\mathrm{XY}$ plots for soils (horizons) and wine, $\mathrm{K}-\mathrm{P}$ and $\mathrm{pH}-\mathrm{Ca}$. Identical nomenclature than Figure 2, but "letter V" identifying wine samples

XY plots between micronutrients (Figure 4) showed different patterns than previous one. The proximity and linearity between the subsuperficial soil samples of PBAcal2 (AS2), CXve3 (CS3) and RRh1 (NS1) with the corresponding wines samples (CV, AV2 and NV1) in Fe-Zn plot suggested a relation between them; a separated linear pattern is observed among the subsuperficial samples of CXve2 (CS2), PBAcal1 (AS1), PBAcal3 (AS3), RRh4 (NS4). The $\mathrm{Mn}-\mathrm{Cu}$ plot showed linearity for almost all sub-superficial soil samples; linearity between wine samples appears no real (scale effect). 


\section{Macrothink}

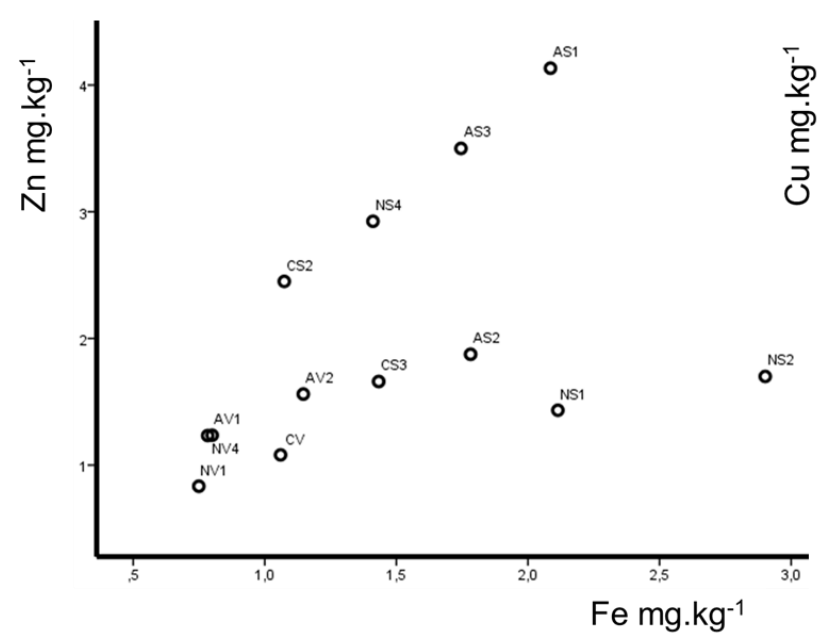

Figure 4. Comparative $\mathrm{XY}$ plots for soils (horizons) and wine, $\mathrm{Fe}-\mathrm{Zn}$ and $\mathrm{Mn}-\mathrm{Cu}$. Identical nomenclature than Figure 2, but letter "V" identifying wine samples

A comparison between results of factor analysis in sub-superficial soil samples (8 means) and wines samples (5 means) is presented in Table 5. Both process explained about $90 \%$ of total variance with three factors. The variables $\mathrm{pH}, \mathrm{Ca}$ and $\mathrm{Mg}$ in factor $1 ; \mathrm{pH}, \mathrm{Cu}$ and $\mathrm{Zn}$ in factor 2 and $\mathrm{P}$ in factor 3 were mutual in both processes. However, $\mathrm{K}$ appeared only in soil and $\mathrm{Mn}$ showed opposition for factor 1; and in wine, Fe substituted Mn (factor 2) and K substituted Fe (factor 3). So, phenomena appear similar but not exactly the same.

Table 5. Associations related to sub-superficial soils samples (8) and wine samples (5) for the chemical variables. EVAR = Explained variance

\begin{tabular}{lllll}
\hline \multirow{2}{*}{ Factor } & \multicolumn{3}{l}{ Soil (Sub-superficial) } & Wine \\
\cline { 2 - 5 } & Association & EVAR & Association & EVAR \\
\hline 1 & $\mathrm{pH}, \mathrm{Ca}, \mathrm{K}, \mathrm{Mg},-\mathrm{Mn}$ & $46 \%$ & $\mathrm{pH}, \mathrm{Ca}, \mathrm{Mg}, \mathrm{Mn}$ & $43 \%$ \\
2 & $\mathrm{pH}, \mathrm{Cu}, \mathrm{Mn}, \mathrm{Zn}$ & $29 \%$ & $\mathrm{pH}, \mathrm{Cu}, \mathrm{Fe}, \mathrm{Zn}$ & $33 \%$ \\
3 & $\mathrm{Fe}, \mathrm{P}$ & $16 \%$ & $\mathrm{~K}, \mathrm{P}$ & $14 \%$ \\
\hline
\end{tabular}

\subsection{Relative Accumulation Indexes}

Relative accumulation indexes were nulls in some horizons (background level) or very variable for A horizon and sub-superficial horizon, especially for PBAcal1, PBAcal3 and RRh1 (Table 6). Similar indexes were used for comparison of geochemical samples of sediments and soils (Filippini-Alba et al., 2008). Wine composition showed low variability. Pearson correlation coefficient of RIA against RIS was 0.38 , however the value was incremented to 0.76 when outliers were discarded (CXve2 and RRh1). When mean values were considered for declivity intervals, the correlation coefficient against (RIA + RIS) was $-0,343$ and value was $-0,887$ when the samples with high declivity were discarded (CXve2, CXve3 and RRH4). 
Table 6. Relative accumulation indexes for A horizon (RIA), Sub-superficial horizon (RIS) and Wine (RIW). -/+ = impoverishment/enrichment

\begin{tabular}{|c|c|c|c|c|c|c|c|}
\hline \multirow{2}{*}{ Soil } & \multirow{2}{*}{ RIA } & \multirow{2}{*}{ RIS } & \multirow{2}{*}{ RIW } & \multirow{2}{*}{ Declivity } & \multicolumn{3}{|c|}{ Related elements } \\
\hline & & & & & A horizon & Sub-superficial & Wine \\
\hline CXve2 & 0 & -3 & & $20-45 \%$ & & $-\mathrm{Na},-\mathrm{Fe},-\mathrm{P}$ & \\
\hline CXve3 & 0 & -1 & 0 & $20-45 \%$ & & & \\
\hline PBAcal1 & 2 & 5 & 0 & $3-8 \%$ & $+\mathrm{Mg},+\mathrm{K}$ & $+\mathrm{Ca},+\mathrm{K},+\mathrm{P},+\mathrm{Cu},+\mathrm{Zn}$ & \\
\hline PBAcal2 & 0 & -1 & $?$ & $8-13 \%$ & & $-\mathrm{P}$ & 577 \\
\hline PBAcal3 & -4 & -2 & 2 & $13-20 \%$ & $-\mathrm{Ca},-\mathrm{K},-\mathrm{Mg},-\mathrm{P}$ & $-\mathrm{Ca},-\mathrm{K},-\mathrm{Mg}-\mathrm{P},+\mathrm{Mn},+\mathrm{Zn}$ & $+\mathrm{He},+\mathrm{Zn}$ \\
\hline RRh1 & 3 & -2 & 0 & $3-8 \%$ & $+\mathrm{Ca},+\mathrm{Mg},+\mathrm{Na}$ & $\mathrm{Na},-\mathrm{P},-\mathrm{Cu},-\mathrm{Zn}$ & D 7n \\
\hline $\mathrm{RRh} 2$ & 0 & 0 & U & $8-13 \%$ & & & $+\mathrm{P},-\mathrm{Zn}$ \\
\hline RRh4 & 1 & 1 & -1 & $20-45 \%$ & $+\mathrm{P}$ & $-\mathrm{Na},+\mathrm{K},+\mathrm{P}$ & $-\mathrm{P}$ \\
\hline
\end{tabular}

\section{Discussion}

Statistics of groups organized by first order of BSSC and horizon showed significant data variability especially when the comparison A horizon against sub-superficial horizon was made (Table 2). Al and $\mathrm{P}$ contrasts suggested the influence of managing operations as $\mathrm{pH}$ correction and fertilization. Thereby, some outliers were discarded.

Soil depth is suggested as a significant pedological parameter for terroir effect (Haynes, 1999; Coipel et al., 2006). Declivity is also mentioned, due to its participation in water soil circulation (Filippini-Alba et al., 2017). The use of means by class of soil was validated because of significance of Kruskall-Wallis nonparametric test for these groups, for almost all chemical variables in some horizon and granulometric variables for sub-superficial horizon. Alteration of A horizon was confirmed when the means of the granulometric variables organized in that way showed equality for that test, so with distribution by chance. Line graphs confirmed these facts too (Figure 2). An anomaly of Na in smooth-wavy relief (RRh1) suggested accumulation of this mobile element. Anyway, this information was considered doubtful due to its punctual nature.

Contents of $\mathrm{Ca}, \mathrm{K}, \mathrm{Mg}, \mathrm{P}$ and $\mathrm{pH}$ in $\mathrm{A}$ horizon and sub-superficial horizons correlated between them, with linear patterns in the XY plots (Figure 3). Anyway, the wine samples appeared isolated without correlation with macronutients of soil. $\mathrm{K}$ and $\mathrm{P}$ contents in wine appeared strongly affected by vinification (Figure 3). A different condition was evident for Fe-Zn plot (Figure 4), when some wine and sub-superficial horizon samples occurred according to a linear pattern, suggesting a clear correlation, confirmed by pair association (grapes corresponding to the same class of soil). $\mathrm{Mn}-\mathrm{Cu}$ plot (Figure 4) showed soil samples linearity only. As other works showed, more trace elements must be considered for better results in that sense (Bălc et al., 2018; Catarino et al., 2018).

Factor analysis explained about $90 \%$ of total variance with three factors in the case of sub-superficial horizon and wine. The first factor related to $\mathrm{pH}$ and earthy alkaline elements, the second one related to $\mathrm{pH}$ and heavy metals and the third one related to $\mathrm{P}$ and one metal. Factors were similar for soil and wine, but not equal. Legacy processes between soil and wine can be suggested.

The Relative Accumulation Indexes showed a characteristic behavior for each horizon and 
class of soil, except Cxve3 and RRh2 with background level. Sum of RIA and RIS correlated to soils with declivity lesser than $20 \%$. Values of RIA and RIS suggest more control of declivity for the horizontal variability than control by type of soil. Some wines were characterized by Fe, $\mathrm{P}$ and $\mathrm{Zn}$ values. Enrichment of $\mathrm{Zn}$ in PBAcal3 and impoverishment of $\mathrm{Zn}$ in RRh1 occurred also in wine.

Since a precision viticulture point of view, this study suggests that the first layer of soil, ten or twenty centimeters, must be discarded, especially if preterit procedures affected the A horizon. Volume of samples might be greater, perhaps, cores of $10 \mathrm{~cm}$ diameter and $50 \mathrm{~cm}$ depth would be the ideal condition, and so data precision would be improved. Sub-superficial horizon appears as the better layer to be collected, according to two depths if it was possible, to comparison effects.

Results confirmed the tridimensional nature of classes of soil, in the way that a characteristic behavior of each horizon by class of soil was observed. So, all classes of soil must be considered as management zones, with specific treatment in each case. If a detailed map of soils is unavailable, a spatial variability representation of soil features involving altitude, declivity, layer depth, horizon sequence and texture in the scale of the vineyard would be a good approach.

\section{Acknowledgments}

The authors would like to thank the entities who collaborated with this study, Miolo Wine Group for making their vineyards available, and CNPq for providing part of the resources.

\section{References}

Aggelopooulou, K., Castrignanò, A., Gemtos, T., \& DeBenedetto, D. (2013). Delineation of management zones in an apple orchard in Greece using a multivariate approach. Computers \& Electronics in Agriculture, 90, 119-130. https://doi.org/10.1016/j.compag.2012.09.009

Bălc, R., Tămas, T., Popită, G., Vasile, G., Bratu, M. C., Gligor, D. M., \& Moldovan, C. (2018). Assessment of chemical elements in soil, grapes and wine from two representative vineyards in Romania. Carpathian Journal of Earth and Environmental Science, 13(2), 435-446. https://doi.org/10.26471/cjees/2018/013/037

Brown C. E. (1998). Applied Multivariate Statistics in Geohydrology and Related Sciences. Berlin: Springer-Verlag. p. 155-156.

https://doi.org/10.1007/978-3-642-80328-4_13

Catarino, S., Madeira, M., Monteiro, F., Caldeira, I., Sousa, R. B. de \& Curvelo-Garcia, A., (2018). Mineral composition through soil-wine system of Portuguese vineyards and its potential for wine traceability. Beverages, 4(85), 20p.

https://doi.org/10.3390/beverages4040085

Chavarria, G., Bergamaschi, H., Silva, L. C. da, Santos, H. P. dos, Mandelli, F., Guerra, C. C., Flores, C. A., \& Tonietto, J. (2011). Relações hídricas, rendimento e compostos fenólicos de uvas Cabernet Sauvignon em três tipos de solo. Bragantia 70(3), 481-487.

https://doi.org/10.1590/S0006-87052011005000004

Chimento, M. R., Vieira, E. S. F. M., \& Moreira, G. R. (2016). O encontro da tradição com a 
inovação: a indicação geográfica do Vale dos Vinhedos em dois momentos. Revista Brasileira de Gestão e Desenvolvimento Regional, 12(1), 197-219.

Coipel, J., Lovelle, R. B., Sipp, C., \& Leeuwen, C. (2006). Terroir effect as a result of environmental stress depends more on soil depth than on soil type (Vitis Vinifira L. cv. Grenache Noir, Côtes du Rhône, France, 2000). J. Int. Sci. Vigne Vin. 40(4), 177-185. https://doi.org/10.20870/oeno-one.2006.40.4.867

Embrapa (1997). Manual de métodos de análise de solo. Second ed. Embrapa Solos, Rio de Janeiro, RJ: Embrapa.

Farias, C.V.S. (2009). A indústria vitivinícola e o desenvolvimento regional no RS: uma abordagem neoinstitucionalista da imigração italiana aos dias atuais. Revista Brasileira de Gestão e Desenvolvimento Regional 5(2), 64-93.

http://www.rbgdr.net/revista/index.php/rbgdr/article/download/237/162

Filippini-Alba, J. M., Flores, C. A., \& Miele, A. (2012). Modelagem espacial do solo para apoio à viticultura de precisão: Vale dos Vinhedos, Serra Gaúcha, Rio Grande do Sul, Brasil. Revista Brasileira de Viticultura e Enologia 4, 8-17.

Filippini-Alba, J. M., Flores, C. A., \& Miele, A. (2017). Geotechnologies and soil mapping for delimitation of management zones as an approach to precision viticulture. Applied Environmental Soil Science, 1-20. https://doi.org/10.1155/2017/4180965

Filippini-Alba, J. M., Flores, C. A., Miele, A., \& Villani., L. M. (2014). SIG para a gestão vitivinícola no Vale dos Vinhedos, RS. In A.C. Bernardi, J.M. Naime, A.V. Resende, L.H. Bassoi; R.Y. Inamasu (Eds.). Agricultura de precisão: resultados de um novo olhar. Embrapa, Brasília, pp. 368-373.

Filippini-Alba, J. M., Miele., A., Flores, C. A., Pavan, C., Fochesato, M. L., Levien, H. F., \& Zarnott, D. H. (2011). Variabilidade espacial dos atributos físicos e químicos de solo e planta na UP Uva para Vinho, Bento Gonçalves, RS, In R.Y. Inamasu, J.M. Naime, A.V. Resende, L.H. Bassoi \& A.C. Bernardi (Eds.). Agricultura de precisão: um novo olhar. Embrapa Instrumentação, São Carlos, pp. 277-281.

Filippini-Alba, J. M., Souza Filho, C. R. de \& Figueiredo, B. R. de (2008). Análise da assinatura geoquímica de solos e de sedimentos de corrente no Vale do Ribeira (SP) por meio de um sistema de informação geográfica. Revista Brasileira de Geociências, 38(1), 66-77. https://doi.org/10.25249/0375-7536.20083816677

Flores, C. A., Filippini-Alba, J. M., Levien, H. F., Zarnott, D. H., Miele, A., \& Pavan, C. (2011). Levantamento detalhado dos solos para viticultura de precisão. In Anais do Congresso Brasileiro de Ciência do Solo, 33, Sociedade Brasileira de Ciência do Solo, Uberlândia, MG, Brazil.

Flores, C. A., Pötter, R. O., Sarmento, E. C., Weber, E. J., \& Hasenack, H. (2012). Os solos do Vale dos Vinhedos, first ed., Embrapa, Brasília.

Haynes, S. J. (1999). Geology and wine 1. Concept of terroir and the role of Geology. Geoscience Canada 26(4), 190-194.

Haynes, S. J. (2000). Geology and wine 2. A Geological Foundation for Terroirs and potential 
Sub-Appellations of Niagara Peninsula Wines, Ontario, Canada. Geoscience Canada, 27(2), 67-87.

Leeuwen, van C., Roby, J. P., \& Rességuier, L. de (2018). Soil related terroir factors: a review. Oeno one, 52(2), 173-188. https://doi.org/10.20870/oeno-one.2018.52.2.2208

Leeuwen, van C., Roby, J. P., Pernet, D., \& Bois, B. (2010). Methodology of soil based zoning for viticultural terrois. Bulletin de l'OIV, 83(947/948/949), 13-29.

http://www.linherr.ch/cmsFiles/WAL/wal_Media/wal_OIV\%20Bull_2010.pdf\#page=15

MacBratney, A. B., Mendoça-Santos, M. L., \& Minasny, B. (2013). On digital soil mapping. Geoderma, 117(1-2), 3-52. https://doi.org/10.1016/S0016-7061(03)00223-4

Mackenzie, D. E., \& Christy, A. G. (2005). The role of soil chemistry in wine grape quality and sustainable soil management. Water Science and Technology 51(1), 27-37.

https://doi.org/10.2166/wst.2005.0004

Maltman, A. (2013). Minerality in wine: a geological perspective. Journal of Wine Research, 24(3), 169-181. https://doi.org/10.1080/09571264.2013.793176

Miele, A., Flores, C. A., \& Filippini-Alba, J. M. (2014). Efeito do tipo de solo nos compostos fenólicos e na atividade antioxidante do vinho. Revista Brasileira de Viticultura e Enologia 6 (setembro): 40-47.

Prado, H. do. (2007). Pedologia Fácil. Piracicaba: Escola Superior de Agronomia Luiz de Quiroz, SP, Brazil, 105p. https://www.pedologiafacil.com.br/index.php

Proffitt, T., Bramley, R., Lamb, D., \& Winter, E. (2006). Precision Viticulture: A New Era in Vineyard Management and Wine Production. Adelaide: Winetitles. ISBN 978-9756850-4-4. https://www.embrapa.br/en/solos/sibcs/classificacao-de-solos/ordens/cambissolos

Santos, H. G., Jacomine, P., Anjos, L., Oliveira, V., Lumbreras, J., Coelho, M., Almeida, J., Araujo Filho, J., Oliveira, J. \& Cunha, T. Sistema Brasileiro de Classificação de Solos. Rio de Janeiro: Embrapa, e-book, 2018.

https://www.embrapa.br/en/solos/sibcs/classificacao-desolos/ordens/cambissolos.

Warmling, M. T., Albuquerque, J. A., Warmling, M. I., Rufato, L., \& Andognini, J. (2018). Efeito da classe de solo e das condições meteorológicas nas características produtivas e composição da uva Cabernet Sauvignon. Revista Brasileira de Fruticultura, 40(6). https://doi.org/10.1590/0100-29452018035

Yan, L., Zhou, S., Ci-Fang, W., Hong-YI, L., \& Fang, L. (2008). Determination of potential management zones from soil electrical conductivity, yield and crop data. Journal of Zhejiang University Science B (Biomedicine \& Biotechnology), 9, 68-76.

https://doi.org/10.1631/jzus.B071379

\section{Copyright Disclaimer}

Copyright for this article is retained by the author(s), with first publication rights granted to the journal.

This is an open-access article distributed under the terms and conditions of the Creative Commons Attribution license (http://creativecommons.org/licenses/by/4.0/). 